\title{
JĘZYK OJCZYSTY — ZANIEDBANY OBSZAR WYCHOWANIA
}

\author{
„[...] Zaiste ich retoryka była aż nazbyt parciana \\ (Marek Tuliusz obracał się $\mathrm{w}$ grobie) \\ łańcuchy tautologii parę pojęć jak cepy \\ dialektyka oprawców żadnej dystynkcji w rozumowaniu \\ składnia pozbawiona urody koniunktiwu. \\ Tak więc estetyka może być pomocna w życiu \\ nie należy zaniedbywać nauki o pięknie”.
}

Zbigniew Herbert, Potęga smaku

Doniosła rola, jaką język odgrywa w kulturze oraz egzystencji ludzkiej, sprawia, że jest on przedmiotem zainteresowań wielu dyscyplin; przede wszystkim językoznawstwa, ale także: socjologii, antropologii, psychologii oraz wyodrębniających się rozmaitych subdyscyplin, jak socjolingwistyka czy

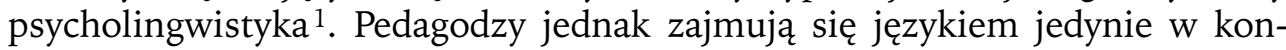
tekście jego nauczania. Nawet pedagodzy społeczni, którzy ujmują człowieka jako jedność psycho-socjo-kulturową, postrzegają relacje człowieka ze środowiskiem społecznym i kulturowym w sposób całościowy, zdają się nie dostrzegać tego podstawowego elementu kultury, jakim jest język. A przecież analiza uwarunkowań zjawisk językowych przez pozajęzykowe czynniki społeczne i kulturowe i odwrotnie (wpływ zjawisk językowych na inne procesy i zjawi-

\section{Adres do korespondencji: gornikowska@poczta.onet.pl}

$1 \mathrm{O}$ języku można mówić $\mathrm{w}$ szerszym i węższym znaczeniu. Język w szerszym tego słowa znaczeniu to skomplikowany system powiązanych ze sobą symboli, będący własnością określonej społeczności. Język w węższym, ścisłym tego słowa znaczeniu — i to ujęcie jest dla nas interesujące - mówiony lub pisany, to złożony zbiór słów (słownik) oraz schematów ich wiązania w większe całości, w zdania, teksty itp. (gramatyka). P. Sztompka, Socjologia. Analiza społeczeństwa, Znak, Kraków 2002, s. 289-290. 
ska społeczne) jest interesującym, a zarazem płodnym poznawczo obszarem badań.

\section{ROLA JĘZYKA W PROCESIE WYCHOWANIA}

W pedagogice społecznej funkcjonuje pojęcie niewidzialnego środowiska wy chow aw c z e go, upowszechnione przez Helenę Radlińską. Niewidzialne środowisko wychowawcze, będące przeciwieństwem środowiska materialnego, obejmuje idee, wierzenia, więź społeczną; odgrywa w życiu człowieka szczególnie doniosłą rolę: ukazuje pewne hierarchie wartości, wpływa na motywy postępowania, pośrednio przekształca życie ludzkie. Jego oddziaływanie zachodzi między innymi dzięki kontaktom z wybitnymi ludźmi, którzy są twórcami nowych idei, mówiła Radlińska ${ }^{2}$.

To, co Radlińska nazywa niewidzialnym środowiskiem wychowawczym, socjologowie określają mianem kultury. Piotr Sztompka mówi o kulturze idealnej lub inaczej świadomości społecznej, Florian Znaniecki używa pojęcia kultury ideacyjnej. Obaj zwracają uwagę na rolę języka. Jak pisze Sztompka: kultura dostarcza nam gotowych treści (wierzeń, przekonań, poglądów), ale przede wszystkim tego fundamentalnego narzędzia, bez którego myślenie i formułowanie jakichkolwiek przekonań byłoby niemożliwe - języka, słów oraz całych konstrukcji językowych ${ }^{3}$.

Rolę języka w przystosowaniu się jednostki do rzeczywistości ponad osiemdziesiąt lat temu dostrzegł Edward Sapir. W pracy pt. Language (1921) pisał: „Widzimy, słyszymy i w ogóle doświadczamy tak a nie inaczej, ponieważ nawyki językowe naszej społeczności predysponują nas do określonych wyborów interpretacyjnych" ${ }^{4}$. Sapir postawił tezę, że język, będący głównym narzędziem socjalizacji, jednocześnie wpływa na sposób organizacji danych sensorycznych, sposób myślenia, sposób postrzegania społeczeństwa i natury. Bardzo podobnie postrzegał te kwestie Benjamin Lee Whorf. Zauważył on, że porządkowanie świata za pomocą pojęć, nadawanie sensów w taki a nie inny sposób, wynika z faktu, że w społeczności językowej, do której należymy, obowiązują pewne reguły, wzorce językowe i bez ich zaakceptowania nie jesteśmy w stanie mówić. Nieświadomi tego staliśmy się sygnatariuszami pewnej umowy i choć nigdy nie została ona wyrażona explicite, a tym bardziej spisana, to przecież ma moc bezwzględnie obowiązującą. A konsekwencje są ogromnej wagi, dla nauki

\footnotetext{
2 Tak samo pojmował tę kwestię Stefan Żeromski. Przekonany, że społeczeństwo należy wychowywać, pragnął to czynić za pomocą własnej twórczości. Dzięki książkom zamierzał zmieniać ludzi, wzbudzać w nich refleksję moralną, historyczną i polityczną. Zob. W. Orliński, Znowu w Obrzydłówku, „Gazeta Wyborcza”, 9-10 grudnia 2000; Gdzie sa nasze szklane domy? Andrzej Mencwel w rozmowie z Wojciechem Orlińskim, „Gazeta Wyborcza”, 3-4 marca 2001.

3 P. Sztompka, Socjologia, cyt. wyd., s. 288.

4 Cyt. za: Z. Bokszański, A. Piotrowski, M. Ziółkowski, Socjologia język, Wiedza Powszechna, Warszawa 1977, s. 18.
} 
i praktyki. Badacze, uczeni - w tym samym stopniu nieświadomi sygnatariusze umowy co przeciętny użytkownik języka - nie potrafią myśleć o rzeczywistości ani opisać jej całkowicie bezstronnie. Podobnie rzecz ma się z ludźmi praktyki, na przykład wychowawcami. „Wszystkich nas krępują pewne prawidła interpretacji, nawet wówczas, gdy sądzimy, że jesteśmy wolni" — konstatuje Whorf 5 .

Charles Wright Mills, który podjął próby zastosowania idei Sapira i Whorfa do społeczeństw industrialnych, stwierdza: „Nasze zachowanie i percepcja, nasza logika i myślenie podlegają kontroli systemu językowego. Wraz z językiem nabywamy zespół norm i wartości" ${ }^{6}$. Zdaniem wielu wybitnych badaczy, nie ma dziś wątpliwości, że istnieją przyczynowe związki pomiędzy językiem a myśleniem i postrzeganiem. Ludwig Wittgenstein porównał rzeczywistość językową (strukturę języka) do klatki, w której tkwimy i z której nie da się uciec, a która zarazem ogranicza oglądanie świata zewnętrznego, rzeczywistości pozajęzykowej. Widzimy zatem tyle, na ile pozwala nam nasz język. „Granice mojego języka oznaczają granice mojego świata" 7 — brzmi po wielokroć przytaczana myśl Wittgensteina.

Związek języka i myślenia dostrzegł także Edward Hall. W pracy Ukryty wymiar zauważył: „Język jest czymś więcej niż tylko środkiem wyrażania myśli. W gruncie rzeczy stanowi on główny czynnik kształtujący myślenie”. Hall porównał umysł człowieka do komputera, a język, którym mówimy do programu komputerowego i stwierdził: „Jak komputer, umysł człowieka może rejestrować i porządkować rzeczywistość tylko w zgodzie z programem" 8 .

W istocie rzeczy mamy więc do czynienia z zależnością dwustronną społeczeństwo tworzy język, którym się posługujemy, i odwrotnie — język tworzy społeczeństwo9. Robin Lakoff ujęła tę myśl następująco: „Język posługuje się nami $\mathrm{w}$ nie mniejszym stopniu, niż my posługujemy się językiem" 10 .

5 Zob. B. L. Whorf, Język, myśl i rzeczywistość, tłum. T. Hołówka, PIW, Warszawa 1982, s. 285. W artykule Jezykoznawstwo jako nauka ścisła Whorf rozwija tę myśl: „Wszyscy ulegamy pewnemu złudzeniu dotyczącemu mowy: sądzimy, że jest ona zjawiskiem całkowicie spontanicznym i nieskrępowanym, narzędziem, które zaledwie "wyraża» coś, co pragniemy wyrazić. To iluzoryczne wrażenie powstaje wskutek tego, że elementy normatywne w pozornie swobodnym toku wypowiedzi mają charakter tak autokratyczny, iż obligują one nadawcę bądź odbiorcę w sposób równie nieświadomy, co władza praw natury" (tamże, s. 296).

${ }^{6}$ Cyt. za: Z. Bokszański, A. Piotrowski, M. Ziółkowski, Socjologia języka, cyt. wyd., s. 26.

${ }^{7}$ L. Wittgenstein, Tractatus logico-philosophicus, cyt. za: M. Ziółkowski, Język i komunikowanie, w: Encyklopedia socjologii, t. 1, Oficyna Naukowa, Warszawa 1998.

8 E. T. Hall, Ukryty wymiar, tłum. T. Hołówka, PIW, Warszawa 1976, s. 26.

9 E. Benveniste, Struktura języka i struktura społeczeństwa, w: Jezzyk i społeczeństwo, M. Głowiński (red.), Czytelnik, Warszawa 1980.

10 R. Lakoff, Język a sytuacja kobiety, tłum. U. Niklas, w: Jezzyk a świetle nauki, B. Stanosz (red.), Czytelnik, Warszawa 1980, s. 239. 
Stawiam tezę, że zdecydowana większość osób zajmujących się zawodowo oddziaływaniem wychowawczym jest nieświadoma obydwu wymienionych zależności; sami posługujemy się językiem mało refleksyjnie i zupełnie nieświadomi jesteśmy tego, że regułom języka podlegamy.

Język jest wytworem kultury ideacyjnej, ukształtowanym w interakcji społecznej, wyuczanym i przekazywanym z pokolenia na pokolenie (posługiwanie się językiem: mówienie, rozumienie innych, pisanie, czytanie, wymaga uczenia się). Tak zwany język standardowy - skodyfikowany, posiadający formę pisaną, przekazywany w trakcie edukacji szkolnej i używany w administracji publicznej - współtworzy poczucie odrębności narodowej i narodowej identyfikacji, łączy członków danej wspólnoty, przeciwstawiając ich członkom innych wspólnot ${ }^{11}$.

Jest także podstawowym medium komunikacji międzyludzkiej, kontaktów i interakcji (ustnej, pisemnej, a także wirtualnej), tworzenia i utrzymywania więzi społecznej (jest wiązadłem solidarności społecznej, według Znanieckiego ${ }^{12}$ ). I jest, o czym wspomniałam wcześniej, narzędziem poznania oraz interpretacji rzeczywistości, świadomości i samoświadomości. Umożliwia, w postaci pisanej, kumulację dorobku kulturowego.

Idee kształtujące myślenie i odczuwanie dzieci, młodzieży i dorosłych (kobiet i mężczyzn), zachęcające lub zniechęcające do określonych działań, idee, w imię których przeobrażamy rzeczywistość, oddziałujemy wychowawczo na jednostki i środowiska, są czerpane z kultury. To właśnie książki i wszelkie inne teksty pisane (legendy, poezja, beletrystyka, dzieła humanistyczne i ekonomiczne, publicystyka i inne), obecnie udostępniane także drogą elektroniczną, dostarczają odbiorcom symboli, znaków kulturowych, za pomocą których porządkują oni swój świat. Treści czytanych książek i pism są przekazywane przy użyciu języka. Język jest bodaj najważniejszym elementem środowiska niewidzialnego, a jednocześnie (nawet $\mathrm{w}$ formie pisanej lub drukowanej) sam jest niewidzialny, w tym sensie, że jego znaczenie jest nieuświadamiane przez pedagogów. Nadszedł czas, aby podjąć refleksję nad językiem, włączyć ją do obszaru rozważań o wychowaniu.

Dla pedagoga mogą być interesujące wszystkie wymienione funkcje, albo inaczej — aspekty rozważań nad językiem ${ }^{13}$.

11 Wspólnoty komunikacyjne, jak pisze Marek Ziółkowski, mają zazwyczaj złożony repertuar językowy, składający się z wielu podsystemów, takich jak: języki etniczne, dialekty, gwary ludowe i miejskie, żargony, języki zawodowe. M. Ziółkowski, Język i komunikowanie, cyt. wyd., s. 372.

12 F. Znaniecki, Wspótczesne narody, tłum. Z. Dulczewski, PWN, Warszawa 1990, s. 18. P. Sztompka, Socjologia, cyt. wyd., s. 291-292.

13 By posłużyć się najbliższym przykładem - niedawny spór ministra edukacji z nauczycielami o kształt listy lektur to przejaw różnic w ocenie dorobku kulturowego, przekazywanego za pomocą słowa, dorobku w sensie idei zawartych w tekstach, a także wartości języka literackiego: Conrad i Gombrowicz czy Dobraczyński? 


\section{TRADYCJE DBAŁOŚCI O JĘZYK OJCZYSTY}

Języki narodowe ceni się obecnie bardzo wysoko, dając temu wyraz w odpowiednich sformułowaniach, także $\mathrm{w}$ formie ustaw ${ }^{14}$. Dobrym tego przykładem jest Francja ${ }^{15}$. Ustawodawstwo francuskie broni języka francuskiego jako podstawowego składnika tożsamości i dziedzictwa Francji, a podstawowe normy prawne zostały uregulowane ustawą o używaniu języka francuskiego (z 31 grudnia 1975 r.).

Dbałość o język ojczysty nie zawsze jednak obowiązywała, o czym przypomina Florian Znaniecki w pracy Wspótczesne narody. Różnice prestiżu, jakim cieszyły się poszczególne języki narodowe, zwłaszcza w oczach klas wyższych, powodowały, że niełatwo było wpoić przekonanie o równej z innymi wartości języka ojczystego. W drugiej połowie XVIII i pierwszej połowie XIX wieku szlachta całej środkowej i wschodniej Europy ceniła język francuski znacznie wyżej od własnych języków narodowych ${ }^{16}$.

Prestiż danego języka wiąże się $\mathrm{w}$ sposób oczywisty z prestiżem powstałej w tym języku literatury. Dlatego nauczanie i podkreślanie znaczenia literatury narodowej stało się powszechną praktyką wraz z wprowadzeniem obowiązku szkolnego ${ }^{17}$. Jeśli chodzi o język polski, to należy przypomnieć, że literatura narodowa, normy i standardy językowe zaczęły się kształtować W XVI wieku ${ }^{18}$ (do końca XV wieku prawie wszyscy polscy pisarze używali języka łacińskiego). Powstaje wówczas zaczyn polskiego języka literackiego, wykształca się tożsamość narodowa, krystalizują się poglądy na temat tego, czym jest państwo, a przede wszystkim, kim jest człowiek. Począwszy od renesansu zaczęto tworzyć słowniki i gramatyki współczesnych języków narodowych, na wzór słowników i gramatyk starożytnej greki i łaciny. W renesansie na nieporównanie wyższym poziomie aniżeli dzisiaj była także kultura retoryczna.

14 Ochronę prawną języka uregulowały ustawą m.in.: Belgia, Litwa, Łotwa, Słowacja, Macedonia, Republika Irlandii. Z kolei Austria i Kanada status języka państwowego zawarły w konstytucji. Niemcy status swojego języka jako państwowego regulują przez deklarację preambuły do konstytucji oraz ochronę prawną urzędowej pisowni ustalonej przed blisko stu laty, jeszcze w 1901 r., na II Konferencji Ortograficznej w Berlinie.

15 Tradycje dbałości o język są tam odległe w czasie. Już w 1539 r. król Franciszek I wydał dekret nakazujący sporządzenie wszystkich aktów prawnych w języku francuskim. W 1635 r. kardynał Richelieu założył Akademię Francuską, której zadaniem była i jest w dalszym ciągu troska o język francuski.

16 Podobna była sytuacja w Indiach. Znaniecki pisze o tym, jak niełatwym zadaniem dla hinduskich przodowników narodowych było przełamanie prestiżu, jakim język angielski cieszył się wśród klas wyższych Indii. F. Znaniecki, Wspótczesne narody, cyt. wyd., s. 158.

17 Tamże, s. 159.

18 Tadeusz Ulewicz, profesor Uniwersytetu Jagiellońskiego, datuje początek okresu literatury staropolskiej na rok 1470, czyli czas ukazywania się pierwszych polskich druków. K. Janowska, Poeci z naszej planety, „Polityka”, 17 grudnia 2005, s. 70. 
I właściwie od początku funkcjonowania polszczyzny jako języka kultury, religii i polityki widoczna była troska o nią. Warto również podkreślić, za znawcami literatury staropolskiej, że w renesansie język, rozmowa były traktowane jako instrumenty oddziaływania wychowawczego. Upowszechnił się model zmiany człowieka poprzez literaturę (tak bliski Żeromskiemu). Jesteś taki, jak mówisz - uważali staropolscy humaniści ${ }^{19}$. Tę samą myśl wyrazi kilkaset lat później filozof niemiecki Ludwig Wittgenstein, a socjolog brytyjski Basil Bernstein wskaże na zależność języka od usytuowania w strukturze społecznej.

Upadek państwowości w okresie Oświecenia spowodował, że troska o język nabrała szczególnego charakteru. Język polski stał się podstawową wartością jednoczącą rozbity i zdegradowany naród, jego najważniejszym spoiwem. W dobie nowożytnej troska o język wynikała przede wszystkim z pobudek patriotycznych. Nauczanie w języku ojczystym miało kluczowe znaczenie dla utrwalenia więzi narodowych i związków młodego pokolenia z polskością. Konsekwentnie zwalczano germanizmy i rusycyzmy, aby przeciwstawić się administracyjnemu naporowi języków zaborców.

Po odzyskaniu niepodległości w 1918 r. zaistniały warunki do działań administracyjnych mających na celu stworzenie oficjalnie obowiązujących norm i przepisów językowych. Okres międzywojenny był dla polszczyzny szczególnie doniosły; ogromną pracę wykonano w zakresie ujednolicenia języka życia państwowego, reformy ortografii, ustalenia terminologii, kształtowania języka w szkolnictwie itp. Po drugiej wojnie światowej także wystąpiło wiele istotnych dla języka procesów, a normą prawną stał się dekret z dnia 30 listopada $1945 \mathrm{r}$. o języku państwowym i języku urzędowania rządowych i samorządowych władz administracyjnych. Bardzo skromny treściowo obowiązywał ponad pół wieku.

W epoce transformacji, w roku 1999, dokładnie dziesięć lat po zmianie ustroju politycznego, gospodarczego i społecznego w Polsce (a zarazem w drugim roku obowiązywania nowej konstytucji), w odpowiedzi na dokonujące się zmiany o charakterze globalnym i w trosce o ochronę wartości, jaką jest język narodowy, Parlament Rzeczypospolitej Polskiej uchwalił Ustawę o języku polskim ${ }^{20}$. Teraz jest niezmiernie ważne, aby nie poprzestać na zapisie, lecz autentycznie zaangażować się w działania na rzecz rozwoju języka.

\section{WARTOŚĆ JĘZYKA OJCZYSTEGO W DOBIE GLOBALIZACJI}

Język, podobnie jak kultura, może należeć do społeczności o różnej skali. Najczęściej kojarzymy język z grupami etnicznymi czy narodowymi ${ }^{21}$. Wspól-

19 Tamże.

20 Ustawa z dnia 7 października 1999 r. o języku polskim, wraz z późniejszymi zmianami. DzU 1999 nr 90 poz. 999, DzU 2000 nr 29 poz. 358, DzU 2003 nr 73 poz. 661, DzU 2004 nr 92 poz. 878.

${ }^{21}$ P. Sztompka, Socjologia. Analiza społeczeństwa, cyt. wyd., s. 290. 
nota językowa może być postrzegana jako istotny element definicyjny narodu (takiego też argumentu — odrębności języka ${ }^{22}$ - użyli zapewne przedstawiciele mniejszości śląskiej, gdy przed Europejskim Trybunałem Praw Człowieka w Strasburgu, w latach 2001 i 2004, zabiegali o uznanie narodu śląskiego).

Historycy kultur narodowych zgodni są co do tego, że podstawowym elementem kultury narodowej jest właśnie wspólny język, język literacki, używany głównie w piśmiennictwie świeckim, którego standardowe reguły oddają gramatyki i słowniki ${ }^{23}$. Kultura narodowa to przede wszystkim wspólna, swoista, świecka kultura piśmienna - zachowywana, rozwijana i będąca przedmiotem ekspansji dzięki stworzonej w tym celu organizacji ${ }^{24}$ (między innymi systemowi wychowania). Każde społeczeństwo w interesie własnego bytu zmuszone jest żądać od swych członków znajomości symboli służących do pośredniego porozumiewania się; dlatego nauka czytania i pisania jest niezbędnym składnikiem wychowania ${ }^{25}$.

Dzisiaj, w wyniku postępów procesu globalizacji, zbiorowością coraz bardziej realną staje się ludzkość, społeczeństwo globalne lub używając terminologii Znanieckiego — społeczeństwo światowe (world society), którego powstanie uczony ten antycypował z ponad półwiecznym wyprzedzeniem ${ }^{26}$.

Pytanie o wartość 27 języka ojczystego w dobie globalizacji jest równoznaczne z pytaniem o wartość kultur narodowych, o prawo do autonomii kulturowej w jednoczącym się politycznie organizmie. W Polsce dyskusja na ten temat szczególnie głośno rozbrzmiewała w okresie kandydowania naszego państwa do Unii Europejskiej. Wątpliwości, poczucie zagrożenia artykułowano donośnie, choć jak się wydaje, w większej mierze było to elementem gry politycznej aniżeli wyrazem troski o narodowe dobra.

22 Warto zauważyć, że przywiązanie Ślązaków do swej gwary, pielęgnowanie jej i starania o uznanie nie są bezowocne. 28 lipca 2007 r. śląski został wpisany jako odrębny język na listę języków Biblioteki Kongresu Stanów Zjednoczonych Ameryki.

23 F. Znaniecki, Wspótczesne narody, cyt. wyd., s. 31.

24 Tamże, s. 40. Kultury piśmienne (literary culture) Znaniecki definiuje jako te kultury, „które ciągłość swego trwania zawdzięczają dziełom pisanym, ponieważ właśnie te dzieła zawierają symboliczne opisy wartości ideacyjnych, na których opiera się solidarność społeczna, oraz symboliczną ekspresję wzorów i norm, których trzymać się powinni ich uczestnicy. Innymi słowy, kultura piśmienna to taka kultura, w której najbardziej wpływowym elementem jest piśmiennictwo (w najszerszym tego słowa znaczeniu)" (tamże, s. 25). Ze względu na treści i znaczenia podstawowych dzieł Znaniecki wyróżnia kultury piśmienne religijne i narodowe, zaznaczając jednocześnie, że pewne elementy jednych mogą być zawarte w drugich (tamże, s. 27-28).

25 F. Znaniecki, Socjologia wychowania, t. 1: Wychowujące społeczeństwo, PWN, Warszawa 1973, s. 204

26 P. Sztompka, Socjologia, cyt. wyd., s. 296-297.

27 Przypomnijmy definicję kluczowego pojęcia: Wartość to dowolny przedmiot materialny lub idealny „W stosunku do którego jednostki lub zbiorowości przyjmują postawę szacunku, przypisują mu ważną rolę w swoim życiu i dążenie do jego osiągnięcia odczuwają jako przymus". J. Szczepański, Elementarne pojęcia socjologii, PWN, Warszawa 1972, s. 97. 
Afirmacja globalizacji lub jej negacja i obrona tożsamości lokalnych zależą od wielu czynników. Jak trafnie zauważa Piotr Sztompka, akceptacja globalizacji będzie z pewnością inna w krajach, które są centrum ekspansywnej kultury, a inna $\mathrm{w}$ krajach, do których dociera ona $\mathrm{z}$ zewnątrz. Istotnym czynnikiem jest siła ekonomiczna, polityczna czy militarna danego kraju, dająca poczucie bezpieczeństwa i znaczenia. Kraje słabsze szukają obrony w kulturze, pielęgnują jej swoistość. Istnieją różnice między środowiskami zawodowymi (niektóre w sposób naturalny są propagatorami globalizacji); pewną rolę może odgrywać miejsce zamieszkania (miasto lub wieś) czy predyspozycje indywidualne ${ }^{28}$.

Żywione przez niektóre środowiska w Polsce obawy co do utraty tożsamości narodowej okazały się przedwczesne. Socjologowie, wśród nich Zygmunt Bauman ${ }^{29}$, są zgodni, że idea państwa narodowego jest obecnie atrakcyjna bardziej niż kiedykolwiek. Nacjonalizmy nie przejawiają tendencji do zanikania mówi Leszek Kołakowski, a naród jako twór naturalny istnieje i ma prawo istnieć $^{30}$. Wraz z narodami istnieją też ich języki.

Jeśli chodzi o nasz język ojczysty, to pod względem liczby użytkowników nie tylko nie stracił, ale wręcz przeciwnie - zyskał. Po przystąpieniu Polski do Unii wzrosło zainteresowanie językiem polskim: wśród eurodeputowanych, pracowników administracji, tłumaczy, studentów. Nasz język stał się piątym pod względem liczby użytkowników językiem Unii ${ }^{31}$.

Mamy jednak świadomość, że postępująca unifikacja nie sprzyja rozwojowi języka. Nakłada to na nas — rodzimych użytkowników i użytkowniczki języka - określone zobowiązania. Konieczna jest aktywna postawa dbałości o język jako sposób ochrony tożsamości narodowej w procesie globalizacji. Od najmłodszych lat powinniśmy wpajać naszym wychowankom, że bogactwo i różnorodność kulturowa Europy są możliwe tylko pod warunkiem

28 P. Sztompka, Socjologia, cyt. wyd., s. 246.

${ }^{29}$ Z. Bauman, Od plemion do narodów i z powrotem, w: Z. Bauman, Ponowoczesność jako źródto cierpien, Sic!, Warszawa 2000, s. 354; zob. też: M. Król, Telewizja i demokracja. Postowie, w: J. Condry, K. Popper, Telewizja. Zagrożenie dla demokracji, tłum. M. Król, Sic!, Warszawa 1996, s. 70-71; J. Chłopecki, Ciagtość, zmiana i powrót. Szkice z socjologii wychowania, WSP, Rzeszów 1993, s. 71-73.

30 L. Kołakowski, Demokracja jest przeciwna naturze, w: L. Kołakowski, Mini wykłady o maxi sprawach. Seria trzecia i ostatnia, Znak, Kraków 2001; L. Kołakowski, Z wszystkiego można wykuć pałkę. Bronisław Wildstein rozmawia z Leszkiem Kołakowskim, „Przegląd Polityczny” 2000, nr 43; E. Górnikowska-Zwolak, Dokąd zmierza wychowanie? Rozważania o polskim spoleczeństwie, państwie $i$ wartościach jednoczacych naród, „Ruch Pedagogiczny” 2003, nr 1-2.

31 Po angielskim, włoskim, francuskim i niemieckim, a obok hiszpańskiego.

Jeśli chodzi o używanie języków w skali świata to najbardziej rozpowszechniony jest chiński, ma około miliarda użytkowników. Na drugim miejscu znajduje się język angielski, liczbę jego użytkowników szacuje się na 350 milionów Na trzecim miejscu znajduje się hiszpański (z 250 mln użytkowników), na siódmym - rosyjski $(150 \mathrm{mln})$, na 10 - niemiecki $(100 \mathrm{mln})$, na 11 francuski $(70 \mathrm{mln})$, na 15 włoski $(60 \mathrm{mln})$. Podaję za: Atlas języków. Pochodzenie i rozwój języków świata, B. Comrie, S. Matthews, M. Polinsky (red.), tłum. P. Gąsiorowski, Oficyna Wydawnicza Atena, Poznań 1998, s. 19. Liczbę użytkowników języka polskiego szacuje się na ok. 50 mln, w tym $10 \mathrm{mln}$ poza granicami kraju. 
pielęgnowania poszczególnych kultur narodowych i regionalnych oraz ich języków.

Na czym polega ochrona języka polskiego, wyjaśnia szczegółowo Ustawa o języku polskim ${ }^{32}$. Ustawa określa również, w sposób bardzo skrótowy, kto jest zobowiązany do ochrony języka polskiego ${ }^{33}$.

W tym kontekście warto raz jeszcze przywołać nazwisko Floriana Znanieckiego - zastanawiał się bowiem nad tym, kto jest odpowiedzialny za tworzenie kultur narodowych (społeczeństw o kulturach narodowych). Wskazał na rolę tzw. indywidualnych przodowników (w oryginale leaders) rozmaitych dziedzin działalności kulturowej, to oni pociągają za sobą rzeszę dobrowolnych naśladowców ${ }^{34}$. Owi liderzy intelektualni pełnią różne role społeczne, są wśród nich: pisarze (świeccy i religijni), historycy i etnografowie, ideolodzy narodowi, artyści, przodownicy ekonomiczni, wreszcie - uczeni. Wszyscy wymienieni są niewątpliwie odpowiedzialni także za kształt języka ojczystego. Ponadto do ich grona należałoby włączyć dziennikarzy (prasy, radia, telewizji, internetu), zawodowych polityków oraz nauczycieli i wychowawców. Na nich - na nas - spoczywa obowiązek dbałości o polszczyznę i świadomego jej użytkowania (także kreowania).

\section{JAKA JEST KONDYCJA POLSZCZYZNY — PRÓBA DIAGNOZY PRZYKŁADY WYKROCZEŃ I ZANIEDBAŃ PRZECIWKO JĘZYKOWI POLSKIEMU}

Przypominając myśl, że jesteśmy zanurzeni w języku jak ryba w wodzie, i odnosząc tę myśl do kondycji obecnej polszczyzny, powiedziałabym, że j e s t é śm y zanurzeni w bylejakości, jesteśmy zanurzeni w bardzo mętnej wodzie. Przedstawię tu przykłady na potwierdzenie tej opinii, jak również niektóre przyczyny niekorzystnego stanu.

Język jest zwierciadłem obyczajów. A obyczaje zmieniają się wraz z ogólnymi przemianami zachodzącymi w świecie: politycznymi, gospodarczymi, kulturowymi. Od roku 1989 Polska uczestniczy w owych przemianach o charakterze ogólnoświatowym. Po pierwsze, jest to wzajemne otwarcie się całych narodów i poszczególnych osób, poznawanie innych ludzi i ich tradycji, ogromne zmiany kulturowe i mentalne, związane z końcem zimnej wojny i dotychczasowego podziału świata na dwa wrogie obozy. Po drugie - demokratyzacja

32 W Art. 3. pkt. 1. Ustawy czytamy: Ochrona języka polega w szczególności na: 1) dbaniu o poprawne używanie języka i doskonalenie sprawności językowej jego użytkowników oraz na stwarzaniu warunków do właściwego rozwoju języka jako narzędzia międzyludzkiej komunikacji, 2) przeciwdziałaniu jego wulgaryzacji, 3) szerzeniu wiedzy o nim i jego roli w kulturze, 4) upowszechnianiu szacunku do regionalizmów i gwar, a także przeciwdziałaniu ich zanikowi, 5) promocji języka polskiego w świecie, 6) wspieraniu nauczania języka polskiego w kraju i za granicą.

33 W Art. 3. pkt. 2 czytamy, że są to: wszystkie organy władzy publicznej oraz instytucje i organizacje uczestniczące w życiu publicznym.

${ }^{34}$ F. Znaniecki, Wspótczesne narody, cyt. wyd., s. 44. 
życia społecznego, w tym zniesienie cenzury w mediach. I wreszcie - rewolucja elektroniczna, powstanie wielkiej przestrzeni wymiany wirtualnej między całymi społeczeństwami i między poszczególnymi ludźmi.

Możliwości poznawania świata, swoboda komunikowania się uwarunkowane są znajomością języków. Język angielski w Polsce gwałtownie zyskał na popularności. Angielszczyzna, nie zawsze poprawna, stała się częścią otaczającej nas przestrzeni, zwroty anglojęzyczne niepostrzeżenie wtargnęły do rozmów Polek i Polaków. W konsekwencji, nieświadomie, w rodzimym języku tworzymykalki wyrażeń anglojęzycznych (czego przykładem jest niezwykle popularne ostatnio Dokładnie!). Co gorsza, także niepostrzeżenie zmieniamy ortografię polską, na przykład pisownię wielkich liter w tytułach i nazwach (błędnie nadużywamy wielkich liter) ${ }^{35}$. Dominacja anglojęzycznej terminologii w ekonomii, informatyce, reklamie powoduje, że wyzbywamy się również form żeńskich rzeczowników (o czym później) ${ }^{36}$.

Miłośników starannej mowy ojczystej ranią nie tylko zapożyczenia, zresztą traktowane $z$ coraz większą życzliwością ${ }^{37}$. Plagą naszego języka są w u lgary z my. Zniesienie urzędowej cenzury oraz komercjalizcja mediów i co się z tym wiąże - walka o czytelników, słuchaczy i widzów stacji telewizyjnych zaowocowały dewaluacją słowa. Nowe obyczaje językowe, czyli swobodne operowanie wulgaryzmami, zaczęli upowszechniać na rynku prasowym redaktorzy tygodnika „Nie”, z redaktorem naczelnym Jerzym Urbanem. W następnych latach „swoboda językowa” rozkwitła. Poziom kultury słowa w mediach (także publicznych, które powinny być w tym względzie wyznacznikiem) pozostawia wiele do życzenia. Przykłady złej praktyki, bylejakości językowej, która aspiruje do miana ekscytującego wyróżnika, można bez trudu znaleźć zarówno w programach radiowych, zwłaszcza adresowanych do młodzieży, jak i telewizyjnych, kierowanych do szerokiego grona odbiorców (nierzadko są to programy z udziałem znakomitych gości) ${ }^{38}$.

Mówimy brzydko, niestarannie, zarówno w środkach masowego przekazu, jak i na ulicy, podwórku, w domu, także w szkole i wreszcie — na sali sejmowej.

35 Błędny zapis tytułów książek polega na pisaniu wielką literą wszystkich głównych słów składających się na tytuł, na przykład Mała Encyklopedia Powszechna zamiast poprawnie Mała encyklopedia powszechna czy Ogniem i Mieczem zamiast Ogniem i mieczem. Zaczynamy mieć kłopoty nawet z przymiotnikami, w sformułowaniu: język polski, prawo polskie itp.

36 Przejmując anglojęzyczne nazewnictwo, w którym nie występuje różnicowanie rodzaju, kobiety aktywne zawodowe przedstawiają się używając form męskich, na przykład asystent, manager, prezes, zastępca, specjalista itd.

37 Okazuje się, że wrażenie, jakoby w latach dziewięćdziesiątych napłynęło więcej zapożyczeń niż kiedykolwiek, jest błędne. Dowiodły tego obliczenia językoznawców. Odczucie zalewu angielszczyzną, przynajmniej w pewnym stopniu, jest skutkiem działalności mediów, w których obce wyrazy pojawiają się z dużą częstotliwością. M. Wolny, Cudze stówka, „Polityka”, 13 listopada 1999. Ponadto zliberalizował się, ogólnie rzecz biorąc, stosunek specjalistów do form potocznych. Od niedawna funkcjonują w naszym języku dwie formy poprawności: wzorcowa i standardowa.

38 Myślę tu na przykład o programie prowadzonym przez Kubę Wojewódzkiego. 
I nie chodzi tu tylko o wulgaryzmy, ale o szerzej rozumianą brzydotę słowa: prostactwo, banalność, nieudolność, niepoprawność, bełkotliwość.

W polskiej mowie publicznej ostatnich lat przestała być ważna wymiana idei, wartości, koncepcji; język służy dokonywaniu przegrupowań odbiorców słów, klasyfikowaniu ich jako sojuszników lub sił wrogich. Język wrogości dominuje; obraza słowna często pojawia się w wystąpieniach publicznych osób, które mają przywilej oddziaływania na myślenie rodaczek i rodaków, dorosłych i młodzieży. Nie ma pozytywnego wzoru debaty o sprawach polskich. Nad stanem języka naszych polityków ubolewają niemal wszyscy ${ }^{39}$; często ci, którzy ubolewają, sami nie są bez winy ${ }^{40}$.

"Język państwa prawa na naszych oczach ulega znieprawieniu" - konstatuje publicysta. „Najważniejsze osoby w państwie, często prawnicy $z$ wykształcenia, pozwalają sobie nie tylko na prawnicze niechlujstwo, ale na świadome pomówienia [...]. Wyznają zasadę, że [...] wolno odłożyć literę kodeksów i przejść na język autorski" ${ }^{41}$. Niepożądane nowe standardy wyznaczane niemal od początku III Rzeczypospolitej zapewne trudno będzie zmienić ${ }^{42}$.

Przywilej wypowiadania się publicznie powinien łączyć się z odpowiedzialnością za słowo, zarówno za jego treść, jak i formę. Osoby publiczne powinny stanowić wzór kultury języka. Niestety, ta potrzeba nie jest dostrzegana. Kandydaci na mężów (i żony) stanu pośpiesznie pobierają lekcje w zakresie tworzenia wizerunku. Dobrze opłacani specjaliści podpowiadają, jak poprawić sylwetkę, zmienić fryzurę, w jakim kolorze koszulę założyć, żeby podobać się wyborcom. Żałować należy, że ów zakres szkolenia nie obejmuje „obsługi języka ojczystego".

Współczesny świat, odzwierciedlany i kreowany przez kulturę masową, został zdominowany przez obraz; dźwięk jest w dalszej kolejności (ale raczej w kategorii przeboju muzycznego, mniej liczy się barwa głosu; chyba że

39 Powoli umyka naszej pamięci, że język w sferze publicznej zmienił się niemal tuż po wielkiej zmianie w roku 1989, wraz z pojawieniem się polityków nowej ery. Już kilkanaście lat temu, w roku 1995, Zdzisław Pietrasik w artykule Nowy cham na nowe czasy pisał, że to prezydent Wałęsa jako pierwszy użył publicznie takich słów, jak: popaprańcy, kolesie. Autor ironicznie zastanawiał się także, czy powstaje już praca doktorska o wpływie Lecha Wałęsy na współczesną polszczyznę. „Polityka”, 21 października 1995.

40 Biskupi polscy obradujący na Jasnej Górze w Częstochowie 26 sierpnia 2007 r. wydali oświadczenie, w którym skrytykowali język, jakiego słuchamy w mediach i parlamencie. Mowę polityków zdiagnozowano jako język nienawiści i agresji. Jednocześnie powszechnie znany przedstawiciel Kościoła, redemptorysta ojciec Rydzyk posługuje się językiem, który przez rzecznika praw obywatelskich Janusza Kochanowskiego został określony jako chamski (w wywiadzie radiowym).

${ }^{41} \mathrm{~K}$. Burnetko, Kto nie nagrywa, ten nie gra, „Polityka”, 25 sierpnia 2007.

42 Warto przypomnieć, że za prezydentury Lecha Wałęsy w obiegu językowym znajdowało się określenie „falandyzacja prawa”. Niektórzy z nas pamiętają również wystąpienie premiera, z wykształcenia prawnika, który z trybuny sejmowej zapewniał, że jeśli prawo nie jest dobre dla obywateli, to nie należy go przestrzegać. 
sprawa jest poważna, jak w przypadku byłej premier Wielkiej Brytanii Margaret Thatcher, z którą specjaliści do spraw wizerunku pracowali nad obniżeniem tonacji głosu). Słowo, jak się wydaje, nie interesuje nikogo ${ }^{43}$; retoryka, a nawet nauka dykcji nie są $\mathrm{w}$ modzie (nie mówiąc o tym, że wielu osobom publicznym przydałyby się także konsultacje u logopedy). Pamiętny przebój Jerzego Sztuhra: „Śpiewać każdy może, czasem lepiej, a czasem trochę gorzej...” moglibyśmy sparafrazować: „Mówić każdy może, zazwyczaj trochę gorzej”.

Ważną konstatację dotyczącą zachowań naszego społeczeństwa poczynił znakomity pisarz Ryszard Kapuściński. Zauważył, że w Polsce zbyt wiele uwagi poświęcamy polityce, a za mało uwagi zwracamy na kulturę społeczną, stosunek człowieka do człowieka. Nieżyczliwość, brak sympatii, nieufność, opryskliwość, cwaniactwo - to wszystko, co Kapuściński określa jako lumpiarstwo (nie w sensie ekonomicznym, ale zachowania się), odróżnia Polskę od starej Europy, a jeszcze bardziej od Afryki, Ameryki Łacińskiej czy Azji ${ }^{44}$.

Żałujemy sobie nawzajem słów grzecznościowych: „dziękuję”, „przepraszam”, „proszę”. Jak wykazuje sondaż „Gazety Wyborczej” na temat sąsiedztwa (znajomości i kontaktów z sąsiadami), wielu Polaków i Polek nie widzi potrzeby używania zwrotu powitalnego: „dzień dobry” wobec osób nieznajomych, nawet jeśli ci nieznajomi mieszkają z nimi w tym samym domu/bloku przez wiele długich lat. Mechanizmy i wzory językowe, którym bezwiednie ulegamy, wpływają na to, jak postrzegamy świat. Język pełen uprzejmości i życzliwości to wyraz otwartości na drugiego człowieka, przejaw zaufania, którego nam, Polakom tak bardzo brakuje, a które jest nieodzowne dla pomyślnego funkcjonowania społeczeństwa demokratycznego ${ }^{45}$.

Praca nad zmianą tego stanu rzeczy to zadanie dla oświaty, dla szkół, to wielkie wyzwanie o charakterze wychowawczym.

Dotychczasowe moje uwagi dotyczyły w większej mierze języka mówionego. Jeśli chodzi o słowo pisane, to kwestia jest jeszcze trudniejsza. Współcześnie ważne jest tempo życia, zmiana. Staramy się nadążyć, czego konsekwencją są różnorodne zachowania. I tu chciałabym wrzucić kamyczek do swojego, nauczycielskiego ogródka. Nauczyciele szkół wszystkich szczebli mają wielkie możliwości, a jednocześnie zadanie — dbałości o język ojczysty. Pytania brzmią: Czy jesteśmy świadomi tego zadania i czy jesteśmy gotowi je realizować? Co czynimy w tym względzie?

43 Inaczej było we wcześniejszych epokach. Krzysztof Podemski na przykład stwierdza, że najbardziej charakterystyczną cechą podróży aż do końca XVIII wieku było nastawienie na słowo, nie na obraz, na ucho i język, a nie oko, na dialog i dyskurs, a nie na patrzenie, zwiedzanie, oglądanie. K. Podemski, Socjologia podróży, Wydawnictwo UAM, Poznań 2004, s. 16.

44 Idę i uśmiecham się do ludzi. Rozmowa z Ryszardem Kapuścińskim, „Polityka”, 3 lutego 2007, s. 34-35.

${ }^{45}$ Demokracja zaczyna się od „dzień dobry”. Z prof. Mirosławą Marody rozmawia Adam Leszczyński, „Gazeta Wyborcza”, 8 sierpnia 2007, s. 1. 
„Szacunek dla słowa jest pierwszym wymogiem dyscypliny, zdolnej wychować człowieka dojrzałego umysłowo, uczuciowo i moralnie" 46 — ta myśl sekretarza generalnego ONZ Daga Hammarskjölda mogłaby stanowić motto dla nas, nauczycieli. Wielu z nas, nauczycielek i nauczycieli akademickich, sprawując opiekę nad dyplomantami, nie znajduje czasu na wskazania dotyczące strony językowej, nie zwraca uwagi na ortografię. Ortografia, w przekonaniu wielu, jest staromodna. Nowoczesny nauczyciel lub nauczycielka chcą raczej nadążać za modą, na przykład używając młodzieżowego języka ${ }^{47}$. Zapewne dlatego błędy ortograficzne, i to nie drobne, ale kardynalne, zdarzają się dosłownie wszędzie: w każdym miejscu i w każdym materiale, na przeźroczach prezentowanych przez profesorów podczas wykładów, w pismach przesyłanych studentom przez uczelnie ${ }^{48}$, w gablotach kościolów.

Widoczna jest także, czasem — słyszalna, nieznajomość regul gramatycznych, na przykład odmiany nazwisk przez przypadki. Wielu nauczycieli, na różnych szczeblach nauczania (także najwyższych) nie stosuje odmiany, bądź to z braku znajomości reguły, bądź z powodu lenistwa. Nie zwraca się też uwagi na błędy popełniane przez studentów.

Potworną plagą języka jest błędna wymowa bądź pisownia rzeczowników w formie celownika (komu? czemu?), np. dzieci - dzieciom, a nie „dziecią należy się opieka”. Tymczasem powszechnie słychać: „dorosłym ludzia...”" „dziękuję wszystkim kibica”; I odwrotnie: rzeczowniki w liczbie pojedynczej, w celowniku, wymawiane są z końcówką „om”, zamiast z „ą". Eksminister sprawiedliwości cieszył się, że mógł odpowiadać przed „komisjom sejmowom”; „Moja mama jest osobom samotnom” — mówi radiosłuchaczka. „Byłam osobom bezrobotnom" - mówi uczestniczka reklamy; I jeszcze z reklamy: „owoce som $z$ dużom ilościom witamin”. „Nasi przeciwnicy majom jednom potężnom broń" - mówi premier.

Nagminnie stosowane są pl e o n a z m y, na przykład „okres czasu”, „miesiąc wrzesień".

Daty wymawiane i pisane są błędnie, na przykład „15 wrzesien”, zamiast „15 (piętnasty) września”.

Jako nauczyciele akademiccy, czyli pracownicy dydaktyczno-naukowi, jesteśmy zobligowani do twórczości własnej. Także wówczas kryterium ilości (szybkości) bywa ważniejsze niż kryterium jakości. Z liczby (a nie jakości) pu-

\footnotetext{
46 D. Hammarskjöld, Drogowskazy, tłum. J. Zieja, Znak, Kraków 1981, s. 81.

47 Pisemny komentarz (ocena przygotowanej prezentacji), jaki otrzymał jeden ze studentów Uniwersytetu Śląskiego od swej nauczycielki akademickiej, brzmiał: „Ekstremalnie zajefajne!”.

$48 \mathrm{~W}$ piśmie przesłanym kandydatowi na studia w AWF w Katowicach komisja rekrutacyjna oświadcza, że „nieprzyjmuje”, a wyraz kluczowy został wyeksponowany przez wytłuszczenie i umieszczenie na środku strony. Pismo jest podpisane przez przewodniczącego komisji, mającego stopień naukowy doktora.
} 
blikacji jesteśmy bowiem rozliczani ${ }^{49}$. Wielu pracowników nauki jest zafascynowanych możliwościami wydawniczymi, jakie istnieją współcześnie, tempem publikowania. Wzajemnie podawane są sobie informacje o tzw. najkrótszych czasach od chwili oddania maszynopisu do ukazania się książki. Możemy wybierać spośród wielu wydawnictw działających na rynku. Jednak we wszystkich tych wydawnictwach starannie oblicza się koszty i często rezygnuje z pracy kilkorga osób: redaktorów, korektorów. Wydaje się, że nikomu to nie przeszkadza. A przecież każdy autor i każda autorka, którzy bodaj raz zetknęli się z procedurą wydawniczą w wersji pełnej, wieloetapowej, powinni zdawać sobie sprawę, że szybkość i tani koszt wydawania książek są odwrotnie proporcjonalne do jakości opublikowanych prac. W rezultacie zalewa nas owa bylejakość, staje się tak powszechna, że przestaje na siebie zwracać uwagę i w końcu zaczyna być normą.

Błędy i tzw. niedoróbki zdarzają się nawet oficynom o uznanej już renomie (i to w podręcznikach!), nie mówiąc o pomniejszych wydawnictwach ${ }^{50}$.

\section{JĘZYK - NARZĘDZIEM OPRESJI KOBIET ${ }^{51}$}

Język jest elementem kultury, zatem i sposoby jego użycia są w dużym stopniu definiowane przez daną kulturę. Każda kultura zawiera też określone wartości. Pytanie o udział wartości kobiecych i męskich w kulturze ogólnej postawili sobie brytyjscy badacze Shirley i Edwin Ardenerowie. Przedstawiają oni świat kultury kobiecej i świat kultury męskiej w postaci dwóch okręgów. Męski jako dominujący jest większy. Kobiecy częściowo zawiera się w nim, a częściowo poza niego wykracza. Ten drugi obszar niektórzy nazywają dzikim, nieprzyswojonym przez kulturę ogólną, niewyartykułowanym. Kobiety według tego ujęcia są grupą pozbawioną głosu. Obydwu grupom znana jest wyłącznie męska część okręgu, gdyż stała się ona przedmiotem ogólnokulturowej le-

49 Zapewne stąd biorą się uwagi w rodzaju tej, z którą miałam do czynienia jako redaktorka pracy zbiorowej: "Jak się komu nie podoba, to niech nie czyta” — powiedziała mi autorka tekstu poproszona o poprawki. W innej sytuacji, podczas dyskusji nad koncepcją pracy doktorskiej, moja uwaga dotycząca poprawności językowej spotkała się z komentarzem jednego z kolegów: „Nie bądź taki Miodek".

$50 \mathrm{~W}$ podręczniku autorstwa Mieczysława Łobockiego pt. Wprowadzenie do metodologii badań pedagogicznych, wydanym przez Oficynę Wydawniczą Impuls w Krakowie, w 2004 r., czytamy: „... badacz narażony jest na przysłowiowe wywarzanie otwartych drzwi [...]" (s. 12); W książce Tadeusza Pilcha i Teresy Bauman: Zasady badań pedagogicznych, wydanej przez Wydawnictwo Akademickie Żak, w 2001 r. (wyd. 2) na stronie 128 czytam (nt. losowania próby): „Sposób przypisania jednostka numerów [...]".

51 Szerzej piszę na ten temat w swej książce zatytułowanej: Myśl feministyczna jako nurt rozważań w pedagogice spotecznej (Wydawnictwo Górnośląskiej Wyższej Szkoły Pedagogicznej im. kard. Augusta Hlonda, Mysłowice 2006) w rozdziale: „Język jako narzędzie w oddziaływaniu socjalizacyjnym". 
gendy. Dlatego teżto, co męskie, staje się zarazem wyznacznikiem normy i wartości 52 .

$\mathrm{Na}$ patriarchalny charakter kultury 53 euroamerykańskiej zwracają uwagę przede wszystkim badaczki o orientacji feministycznej. Ich zdaniem, świat języka jest światem męskim. Ponieważ mężczyzna jest bardziej widoczny w kulturze, to jego słowa są związane $z$ tym, co uniwersalne, ogólne i zawierające inne podmioty. Słowa kojarzące się z kobietą obejmują zwykle specjalne przypadki i wyjątki oraz wyrazy, które wykluczają z ogólności. Ponadto męskie słowa $\mathrm{w}$ większości mają kulturowo pozytywny wydźwięk; wiążą się z władzą, dominacją i wysokim prestiżem; są jednoznaczne. Kobiece słowa kojarzą się $z$ tym, co negatywne, ze słabością, podporządkowaniem, niedojrzałością, banalnością, są dwuznaczne ${ }^{54}$.

Tradycyjne językoznawstwo nie zajmowało się badaniem języka w tym aspekcie i nie budzi to zdziwienia, zważywszy, że podobnie jak inne dziedziny nauki zdominowane było przez mężczyzn. Nawet po powstaniu współczesnego ruchu feministycznego trzeba było wielu lat, by język stał się dla feministek ważnym obiektem badań. Denuncjacją języka (jego struktury) jako ważnego narzędzia opresji kobiet intensywnie zajęly się dopiero w późnych latach siedemdziesiątych XX wieku feministki amerykańskie i francuskie. Wówczas też wypracowano definicję seksizmu językowego, czyli określono, na czym polega opresja kobiet w języku. Dostrzeżono ją w kilku wymiarach ${ }^{55}$ :

1) jako ignorowanie kobiet i ich doświadczenia;

2) definiowanie kobiety w relacji do mężczyzny, często jako osoby podrzędnej;

3) prezentowanie kobiet w sposób stereotypowy;

4) deprecjonowanie kobiet.

Ignorowanie kobiet przejawia się $\mathrm{w}$ tym, że rodzaj męski ma znaczenie uniwersalne, normatywne, tak jak w określeniach: uczniowie, studenci,

52 Por. E. Showalter, Krytyka feministyczna na bezdrożach, „Teksty Drugie” 1993, nr 4/5/6, s. 139-140 .

$53 \mathrm{~W}$ dyskursie feministycznym pojęcie to oznacza „system władzy i dominacji mężczyzn nad kobietami", za sprawą charakteru instytucji społecznych, ekonomicznych i politycznych będący „źródłem opresji kobiet”, a więc ich społecznego podporządkowania. W ten sposób rozumiany patriarchat służy nazwaniu „całości opresyjnych stosunków społecznych doświadczanych powszechnie przez kobiety". Por. M. Humm, Stownik teorii feminizmu, tłum. B. Umińska, J. Mikos, Semper, Warszawa 1993, s. 158-160.

54 F. C. Epstein, Deceptive Distinctions: Sex, Gender and Social Order, Vail-Bellov Press, New York 1988. Podaję za: A. Buczkowski, Czy potrafimy się zrozumieć - język kobiety i język mężczyzny, w: Humanistyka i pteć. III. Publiczna przestrzeń kobiet: obrazy dawne i nowe, E. Pakszys, W. Heller (red.), Wydawnictwo UAM, Poznań 1999, s. 199.

55 Zob. M. Ciechomska, Nieobecność, „Pełnym głosem” 1993, nr 1, s. 43-55; „Women of Europe” 1993, nr 40 pt. Women and Language, s. 32; E. Górnikowska-Zwolak, Feministyczna lingwistyka, w: E. Górnikowska-Zwolak, Szkic do portretu Ślazaczki - refleksja feministyczna, Wydawnictwo Uniwersytetu Śląskiego, Katowice 2004, s. 31-35; A. Buczkowski, Czy potrafimy się zrozumieć..., cyt. wyd., s. $197-220$. 
mieszkańcy, obywatele, rodacy. Rodzaj żeński jest uzupełnieniem, dodatkiem. Kobiecość jest oznaczana i reprezentuje tylko kobiety. Należy przy tym pamiętać, że to, co niewidoczne i nieoznaczone, wydaje się zwykle bytem niezależnym i obiektywnym, a więc niepodatnym na zmiany.

Przemilczanie i manipulacja to skuteczne formy seksizmu językowego. Świat wyłaniający się z tekstów (zamieszczanych w prasie i książkach, przede wszystkim książkach historycznych ${ }^{56}$ ) składa się prawie wyłącznie z mężczyzn. To oni znajdują się na pierwszym planie, podróżują po kraju i świecie, angażują się w życie społeczne, są czynnikiem sprawczym i ofiarami historii. Natomiast przestrzeń, w której występują kobiety, została poddana daleko idącej redukcji. Dlatego dziewczynki i kobiety poszukujące w tekstach odniesień dla siebie, poszukujące wzorów osobowych, symboli niezbędnych do budowania własnej tożsamości po prostu ich nie znajdą.

Męskie definiowanie kobiety polega przede wszystkim na określaniu jej osoby w relacji do mężczyzny, najczęściej jako podrzędnej („żebro Adama"). Najbardziej rozpowszechnionym zwyczajem podtrzymującym takie praktyki jest zmiana nazwiska kobiety po zawarciu związku małżeńskiego ${ }^{57}$. To, co wielu wydaje się takie oczywiste, odkrywa całą swoją arbitralność po dokonaniu zabiegu prostego odwrócenia sytuacji, gdy kobieta nadaje swoje nazwisko mężczyźnie. Sytuacje takie zdarzają się bardzo rzadko.

Stereotypowe przedstawianie kobiet w dużej mierze wiąże się $z$ ignorowaniem kobiecych osiągnięć, odmawianiem zachowań, zainteresowań i zdolności wychodzących poza stereotypy. Kobiety prezentowane są jako osoby łagodne, wrażliwe i ustępliwe, w pełni oddane rodzinie, realizujące się całkowicie $\mathrm{w}$ rolach żony, matki i pani domu. Jeśli myślą o sobie, to przede wszystkim w kategoriach dbałości o urodę. Taki obraz kobiet upowszechniają przede wszystkim czasopisma kobiece ${ }^{58}$, ale także - co dla pedagogów powinno być bardziej niepokojące - podręczniki dla dzieci i młodzieży. W polskich pod-

56 Historia, czyli przekaz zdarzeń minionych utrwalonych za pomocą słowa pisanego, należy do tych dyscyplin naukowych, w których kobiety są ignorowane w sposób ewidentny. Stąd postulat feministek, aby jego opowieść (his story) uzupełnić o jej opowieść (her story), wydobywając z ukrycia prywatną sferę życia, życie codzienne, zwyczaje i obyczaje ludzi.

57 Relacje kobiety wobec mężczyzny dobrze oddawały zwłaszcza dawne formy nazwisk, różnicujące stan cywilny kobiet. Na przykład pani Franczakowa to żona pana Franczaka, panna Franczakówna to jego córka. Innym sposobem określenia kobiety w relacji do mężczyzny było (jest) eksponowanie zawodu wykonywanego przez męża (bądź stanowiska), zwłaszcza jeśli miał profesję cenioną w środowisku. Stąd na przykład pani aptekarzowa, pani radczyni, pani profesorowa.

W tradycji, która zobowiązuje kobiety do przyjmowania i noszenia nazwisk swych ojców i mężów, międzypokoleniowe więzi matrylinearne idą w zapomnienie. Uświadamia nam to filozofka i kulturoznawczyni Jolanta Brach-Czaina, która w książce Błony umystu (Sic!, Warszawa 2003) stosuje przewrotny zabieg. Zamiast nazwiskiem przedstawia się imionami: Jolanta, córka Ireny, wnuczka Bronisławy, prawnuczka Ludwiki.

58 Jeśli nawet bohaterką tekstu będzie kobieta w roli nietradycyjnej, to obowiązkowo zostaje do niej skierowane pytanie: „Jak pani godzi karierę zawodową z życiem rodzinnym?”. 
ręcznikach nie ma kobiet pracujących zawodowo, kobiet obywatelek, kobiet, dla których ważny jest rozwój osobisty ${ }^{59}$. Pomimo ideologicznych deklaracji dotyczących równouprawnienia oraz zobowiązań prawnych podjętych przez Polskę ${ }^{60}$ dzieci nadal uczą się dwóch różnych typów zachowań. Taka socjalizacja wpływa na ukształtowanie podmiotowości i samoświadomości kobiet.

Deprecjonowanie kobiet w języku odbywa się poprzez prezentowanie wyobrażeń kobiet, które je ośmieszają i upokarzają. Dzieje się to na wiele różnych sposobów, na przykład przez negatywne określanie w różnego rodzaju powiedzeniach i przysłowiach ${ }^{61}$.

Innym, bardziej interesującym przykładem deprecjonowania kobiety w języku (w czym uczestniczymy my same) jest określanie dziedzin życia, w których kobieta jest widoczna, słowami o zwyczajowo niższej wartości, na przykład w przypadku zawodów i funkcji: lekarz i lekarka, szef i szefowa, sekretarz i sekretarka. W każdym z powyższych zestawień drugi element, forma żeńska, ma społecznie niższy status ${ }^{62}$. Istnieją nazwy zawodów, które nie posiadają formy żeńskiej (przykładem jest jeden z najbardziej kobiecych zawodów — pedagog, forma żeńska - pedagożka nie funkcjonuje na razie, choć psycholożka pojawia się coraz częściej), bądź takie, których forma żeńska jest rzadko używana, również przez kobiety, ponieważ „gorzej brzmi”. Zapewne dlatego kobiety pracujące w uczelniach wyższych wolą mówić o sobie „nauczyciel akademicki”, zamiast „nauczycielka akademicka”, choć forma nauczycielka jest powszechnie i od dawna przyjęta ${ }^{63}$. Szczególnie razi niepoprawnością, gdy kobieta trudniąca się zawodowo nauczaniem języka ojczystego przedstawia się: ,jestem nauczycielem języka polskiego".

Seksizm językowy przejawia się również w tym, że język jest w określaniu kobiet wulgarny i pogardliwy — przez odwołanie do sfery seksualnej. Stosunek do tej sfery stanowi najważniejszą podstawę stratyfikacji osób płci żeńskiej ${ }^{64}$.

\footnotetext{
59 J. Podgórska, I Bóg stworzyt kretynkę, „Polityka”, 2 czerwca 2007.

60 Konwencja ONZ o Eliminacji Wszelkich Form Dyskryminacji Kobiet została ratyfikowana przez Polskę w 1980 r.

61 Dowcipy o blondynkach czy teściowych stały się tak naturalnym elementem rzeczywistości społecznej, że nikt (nawet kobiety) przeciwko nim nie protestuje. Tymczasem szkodliwość, $z$ pozoru tylko niewinnych, dowcipów eksploatujących stereotypy wykazują badania eksperymentalne współczesnych psychologów. Zob. M. Rotkiewicz, Cała prawda o blondynkach, „Polityka”, 28 lipca 2007.

62 Zob. A. Graff, Świat bez kobiet. Pteć w polskim życiu publicznym, WAB, Warszawa 2001, s. 35-36.

63 Warto odnotować, że choć powoli, to jednak następują w tym względzie zmiany. W tygodniku „Polityka” (2007, nr 3) w artykule poświęconym Marii Janion możemy o niej przeczytać: "nauczycielka akademicka, znawczyni problematyki, historyczka idei”.

$64 \mathrm{~W}$ języku angielskim badaczki doszukały się ponad dwustu słów oznaczających kobiecy promiskuityzm, a dziesięć razy mniej takich słów definiujących mężczyznę, choć w tej dziedzinie istnieje większe społeczne przyzwolenie dla mężczyzn. A. M. Paludi, A. J. Doyle, Sex and Gender, Brown Publishers, Dubuque, Wm. C. 1991, s. 217.
} 
W języku płeć męska uchodzi za nadrzędną i ogólniejszą; ten sposób myślenia jest widoczny $\mathrm{w}$ całej kulturze ( $\mathrm{w}$ nauce, sztuce, prawodawstwie, także w wychowaniu). Słowa, które ludzie tworzą i których używają, są w większości męskiej proweniencji, ponieważ to mężczyźni dysponują władzą ich upowszechniania. Język polski nie odbiega pod tym względem od innych języków, również ma charakter seksistowski ${ }^{65}$. Występują $\mathrm{w}$ nim seksistowskie mechanizmy gramatyki ${ }^{66}$ oraz awersja do formy żeńskiej ${ }^{67}$.

Mówienie o mężczyznach jest więc proste, jednoznaczne i nieskomplikowane. Natomiast wtedy gdy trzeba mówić o kobietach, pojawiają się problemy. Okazuje się — jak stwierdza ironicznie i obrazowo Maria Ciechomska — że: „mój język ojczysty (sic!) odpowiada moim potrzebom życiowym w równym stopniu, co architektura naszych miast potrzebom ludzi niepełnosprawnych" 68 .

Seksistowski język odzwierciedla nierówności, ale również je uprawomocnia, a nawet tworzy, wpływa na nasze - kobiet i mężczyzn - myślenie i zachowania. Za pomocą języka budujemy swą tożsamość, a niektórzy z nas w roli wychowawczyń i wychowawców współkształtują tożsamość swych podopiecznych.

\section{W POSZUKIWANIU ROZWIAZZAŃ PROBLEMU - PRZYKEADY DOBRYCH PRAKTYK}

W polskim społeczeństwie niska jest świadomość wartości języka, język ojczysty nie jest powszechnie postrzegany jako dobro kulturowe. Osoby, które profesjonalnie zajmują się pracą wychowawczą, również nie zwracają należytej

65 Jako przykład niech posłuży cytat z książki Tadeusza Kielanowskiego, Rozmyślania o przemijaniu (Warszawa 1980, s. 94): „Samotny jest człowiek nie mający rodziny, rodzeństwa, ż on y ani przyjaciół". Maria Ciechomska (Nieobecność, cyt. wyd., s. 47-48), która prezentuje ten przykład, czyni w tym miejscu komentarz: „Zdanie «Samotnym jest człowiek nie mający żony» jest równie prawdziwe, co stwierdzenie: «W wieku 13 lat człowiek zaczyna miesiączkować»".

66 Stosowanie męskoosobowej i niemęskoosobowej formy czasowników.

67 Formy żeńskie rzadko występują w języku oficjalnym, urzędowym. Oto przykład pomieszania form męskich i żeńskich potwierdzający, że formy żeńskie pozostawiane są dla sfery prywatnej: (nekrolog) „Z głębokim smutkiem żegnamy inż. Barbarę X wspaniałego n a u c z y ciel a i wychowawcę oraz życzliwą przyjaciółkę i koleża nkę. Serdeczne wyrazy współczucia Rodzinie składają Pracownicy Zespołu Szkół nr 3 w Tychach”. „Echo. Górnośląski Tygodnik Regionalny", 22 sierpnia 2007.

Także w wydawnictwach encyklopedycznych przy nazwiskach kobiecych często padają określenia w formie męskiej. Jako przykład może posłużyć Stownik pedagogów polskich pod red. Wandy Bobrowskiej-Nowak i Danuty Dryndy, Wydawnictwo UŚ, Katowice 1998. Obok nazwisk mężczyzn (w liczbie 194) zamieszczono w nim biogramy 49 kobiet. Prezentowane kobiety są określane pojęciami: pedagog, psycholog, teoretyk wychowania, dydaktyk, historyk, prawnik, społecznik. Nawet w przypadku, gdy formy żeńskie są powszechnie stosowane, o kobiecie mówi się tu „działacz społeczno-oświatowy” (o Stefanii Sempołowskiej) lub „specjalista wychowania przedszkolnego" (o Wandzie Grulowej).

68 M. Ciechomska, Nieobecność, cyt. wyd., s. 43. 
uwagi na język i jego moc oddziaływania. Dlatego konieczne są różnorodne przedsięwzięcia zmierzające do pobudzenia refleksji nad językiem, a w konsekwencji zmiany postaw wobec polszczyzny.

Przykłady dobrych praktyk można znaleźć w różnych obszarach kultury, nie tylko w Polsce, ale i poza nią; różny też jest ich zasięg oddziaływania. Zacznę od instytucji religii i Kościoła (dotąd świadomie omijanych przeze mnie), gdzie dostrzegamy interesujące zmiany właśnie w obszarze języka. W Kościele jednym z najprężniej rozwijających się nurtów teologii posoborowej jest teologia feministyczna ${ }^{69}$ (w Polsce niedostrzegana lub traktowana wyjątkowo nieprzychylnie ${ }^{70}$ ), dla której największym wyzwaniem jest Biblia, a dokładnie - sposób jej odczytywania przez chrześcijan. Księga, która powstała $\mathrm{w}$ środowisku patriarchalnym, ewidentnie dyskryminuje kobiety ${ }^{71}$. Dla współczesnych teologów przekład Biblii jest zagadnieniem niezwykle ważnym; w wersjach anglojęzycznych standardem już stał się język inkluzywny, czyli niewykluczający kobiet. Język ten zaczyna się także pojawiać w przekładach polskich. W najnowszym polskim przekładzie, tzw. Biblii paulińskiej, zamiast „synów” 72 mamy dzieci, co usuwa patriarchalny element tekstu.

Innym przykładem poszukiwania przez przedstawicieli Kościoła adekwatności języka wobec przemian cywilizacyjnych jest powołanie szkoły (a raczej kursów) dla spowiedników ${ }^{73}$. Organizatorzy szkoły, kapucyni, są świadomi, że kontakt z członkami współczesnych społeczeństw i ich nowymi problemami wymaga użycia nowoczesnego języka. Potrzebne są nie tylko nowe metafory, trafiające do użytkowników mediów elektronicznych (jak: modlitwa to pisanie

69 Jest ona praktycznym wyrazem wielkiej idei II Soboru Watykańskiego (1962-1965) — który notabene dopuścił kobiety do studiowania teologii — dążenia do przywrócenia kobietom należnego im miejsca w Kościele.

70 Por. E. Górnikowska-Zwolak, K. Rajca, Poglady przedstawicieli Kościoła na temat miejsca $i$ roli kobiet we wspótczesnym świecie - spojrzenie przez pryzmat feminizmu, w: Role płciowe. Kultura i edukacja, M. Chomczyńska-Rubacha (red.), Wydawnictwo Wyższej Szkoły Humanistyczno-Ekonomicznej w Łodzi, Łódź 2006.

71 Pierwszą próbę nowego jej odczytania podjęła sufrażystka Elizabeth C. Stanton w 1895 r., publikując Woman's Bible (Biblia kobiety). Opatrzyła ona tekst biblijny obszernymi komentarzami wskazującymi fragmenty deprecjonujące kobiety. Teolożki feministyczne zwróciły uwagę na dwa opisy stworzenia człowieka występujące w Księdze Rodzaju i upowszechnienie tego, w którym Ewa powstała po Adamie (podczas gdy opis wcześniejszy akcentuje równość płci, mówi o stworzeniu kobiety i mężczyzny równocześnie).

Odkrywane jest też na nowo macierzyńskie oblicze Boga; na nowo, gdyż już w średniowieczu pojawiały się w niektórych tekstach wyobrażenia Jezusa jako matki. Aleksander Gomola, teolog i językoznawca, odnotowuje, że najbardziej radykalna w tym względzie jest amerykańska teolożka siostra Elizabeth Johnson, która w książce She Who Is zrywa z dotychczasowym przedstawianiem Boga w kategoriach męskich (Pan, Ojciec, Król, itp.) i odwołuje się do biblijnej metafory Boga jako Mądrości stwarzającej i podtrzymującej $\mathrm{w}$ istnieniu świat, przedstawia Ją $\mathrm{w}$ różnorodnych działaniach. A. Gomola, Kościót kobiet, „Gazeta Wyborcza”, 9-10 czerwca 2007, s. 25.

72 W kluczowym dla teologii chrześcijańskiej zdaniu: „Wszyscy zaś jesteście przez wiarę synami Bożymi dzięki waszemu zjednoczeniu z Jezusem Chrystusem" (Ga 3, 26).

73 W 2004 r. w Skomielnej pod Krakowem. 
bloga dla/do Pana Boga), ale także umiejętność zupełnie nowego spojrzenia na pewne kwestie, nowa wrażliwość idąca $w$ parze $z$ nowym językiem ${ }^{74}$.

Pozostając jeszcze przy aspekcie rodzajowości języka, czyli języka uwzględniającego płeć (gender sensitive language), warto odnotować zapis prawny w tym względzie, a mianowicie Rekomendację Komitetów Ministrów Rady Europy z 1990 r., w której zaleca się używanie języka nieseksistowskiego, wprowadzenie terminologii (w tekstach prasowych, administracji i w wydawnictwach) pozostającej $\mathrm{w}$ zgodzie $\mathrm{z}$ zasadą równości płci. Kwestia ta została również podniesiona jako element przygotowania zawodowego dziennikarzy, niestety jeszcze nie w Polsce, lecz w Wielkiej Brytanii ${ }^{75}$.

Kolejnym przykładem zjawiska o charakterze ponadlokalnym, ponadnarodowym, które zasługuje na uwagę w kontekście omawianej problematyki, jest wzrost popularności książki dźwiękowej (e-book, audiobook). Znakomite utwory literatury światowej czytane przez mistrzów słowa, wybitne interpretacje prezentowane $\mathrm{w}$ radiu, a przede wszystkim dostępne na płytach CD i w formie plików dźwiękowych $\mathrm{w}$ internecie, są propozycją adekwatną do zmian współczesnego świata, tempa życia i braku czasu, ze wszech miar godną propagowania. Dodatkowym walorem jest możliwość wspólnego słuchania, czyli jednoczenia miłośników słowa ${ }^{76}$. Warto wspomnieć, że w Stanach Zjednoczonych najważniejsza amerykańska nagroda przemysłu nagraniowego Grammy ma także kategorię „słowo mówione” i w tej kategorii przyznawana jest od 1959 r.

Poszukując dalszych przykładów dobrych praktyk, tym razem z obszaru Polski, warto wspomnieć o inicjatywie Senatu RP, który w trosce o kondycję mowy ojczystej ustanowił (mocą uchwały z dnia 22 grudnia 2005 r.) rok 2006 Rokiem Języka Polskiego. Była to okazja, aby zwrócić się do władz publicznych i Polaków o ochronę, otaczanie opieką i kultywowanie polszczyzny. Był to także dobry moment, aby przypomnieć o konieczności pielęgnowania odmian regionalnych i gwarowych polszczyzny, języków małych ojczyzn.

Inną inicjatywą jest „Dyktando”, czyli ogólnopolskie święto języka polskiego organizowane od dwudziestu lat przez Radio Katowice. Pomysłodawczyni, dziennikarka Radia Katowice, później senatorka RP - Krystyna Bochenek (notabene w czerwcu 2007 r. wybrana do Rady Języka Polskiego przy Polskiej Akademii Nauk ${ }^{77}$ ), wyraża opinię, że brakuje programów upowszech-

74 Trafnie postrzega tę kwestię o. Piotr Śliwiński, podając przykład: „Gdy ktoś doświadczył przemocy ze strony własnego ojca, to mówienie o miłości Boga Ojca nie jest najbardziej fortunne, bo dla niego to doświadczenie negatywne. Wtedy często przytaczam teksty, w których Bóg porównywany jest do matki, np. w księdze Izajasza”. K. Wiśniewska, Nauka spowiedzi. „Gazeta Wyborcza”, 16-17 lipca 2005; Przychodzi Polak do konfesjonatu. Z o. Piotrem Jordanem Śliwińskim rozmawia Łukasz Grzymalski, „Echo Miasta Kraków”, 19 czerwca 2006.

75 Vademecum Dziennikarstwa BBC. Zob. E. Górnikowska-Zwolak, Myśl feministyczna jako nurt rozważań w pedagogice społecznej, cyt. wyd., s. 284-288.

76 M. Strzelecka, Szturm audiobooków, „Gazeta Wyborcza”, 8 sierpnia 2007.

77 Podaję za „Gazeta Wyborcza”, 13 czerwca 2007. Rada Języka Polskiego to instytucja opiniodawczo-doradcza w sprawach używania języka polskiego; powołana 9 IX 1996 r., działa na 
niających polszczyznę w sposób nowoczesny. Jej dyktando jest przykładem, jak to czynić.

Nowe czasy wymagają starannej i adekwatnej edukacji językowej najmłodszych czytelniczek i czytelników. I w ostatnim czasie pojawiły się takie właśnie teksty: niebanalne, z nowatorską fabuła, ciekawe w warstwie językowej ${ }^{78}$. Świadczą o tym, że polscy pisarze (Leszek K. Talko, Joanna Olech, Michał Rusinek) zaczynają traktować młodego czytelnika poważnie. Współczesne książki dla dzieci stanowią zatem kolejny przykład pozytywnych działań.

Wrażliwość na słowo, także $\mathrm{w}$ formie poezji, jest nie bez znaczenia dla codziennego odczuwania i postrzegania świata, funkcjonowania w nim. To Helena Radlińska jest autorką myśli: „Duńczycy robią tak dobre masło, ponieważ młodzież czyta poetów" 79. Propagowanie poezji i poetów ma różne formy w poszczególnych krajach ${ }^{80}$. Rodzimy poeta, prozaik i tłumacz Adam Zagajewski wyraża przekonanie, że w Polsce poezja znajduje wysoką pozycję w przestrzeni kultury; nie brak nowych inicjatyw i pomysłów zakresie jej popularyzacji. Zgajewski zwraca uwagę na projekt „Mój ulubiony wiersz”, pomysł amerykański przejęty przez Ewę Zadrzyńską. Zaowocował on cyklem interesujących filmów, które niosą przesłanie, że poezja to coś znacznie więcej niż lekka rozrywka, to poszukiwanie prawdy o sobie samych i o świecie ${ }^{81}$.

„Konkurs na antysłowo IV RP”, ogłoszony przez tygodnik „Polityka” w końcu maja 2007 r., to jeszcze jeden sposób na pobudzenie wrażliwości, zainteresowania warstwą języka. Autorzy konkursu zapraszają i zachęcają do wychwytywania używanych w życiu publicznym, zwłaszcza politycznym, słów i zwrotów, które zamiast służyć komunikacji, opisywaniu i objaśnianiu rzeczywistości - prowadzą do fałszowania, ukrywania faktów i intencji. W jury

mocy ustawy o języku polskim z 7 X 1999 r. Komisję specjalistów tworzą ludzie nauki i kultury (pisarze, aktorzy, dziennikarze). Wśród ludzi nauki są językoznawcy i literaturoznawcy, ale także filozofowie, historycy, prawnicy, logicy, lekarze, fizycy, informatycy. W tym licznym gronie, blisko czterdziestoosobowym, nie ma niestety pedagoga.

78 A oto przykład języka: „"Ta plugawa książeczka utrwala szkodliwy stereotyp wilka - mięsożercy, czemu dajemy stanowczy odpór" - sprzeciwia się Liga Wilków Polskich". Opinia pochodzi z opisu Czerwonego kapturka, współczesnej książki dla dzieci (autorstwa Joanny Olech), która ukazała się w niezwykle ciekawej serii Niebaśnie (Jacek Santorski\&Co). A. Wolny-Hamkało, Kupa, mości autorzy! „Polityka”, 2 czerwca 2007, s. 76-77.

${ }^{79}$ H. Radlińska, Pedagogika społeczna, Ossolineum, Wrocław 1961, s. 72.

80 W Stanach Zjednoczonych na przykład ustanowiono federalny Miesiąc Poezji. Jest nim kwiecień. Księgarze promują tomy poezji, odbywają się wieczory autorskie, media (zwłaszcza National Public Radio) intensywnie i interesująco propagują poezję i poetów. Istnieje także instytucja Poety Laureata, rezydującego w Bibliotece Kongresu w Waszyngtonie; do jego zadań należy między innymi propagowanie poezji. Niemal na każdym uniwersytecie jest wydział twórczego pisania (creative writing), jego studenci i profesorowie stanowią lobby propoetyckie. Z kolei w Niemczech działa wiele akademii literatury, potęgę stanowią księgarze. Jest to kraj bardzo wielu nagród literackich, przyznawanych przez miasta i miasteczka (niektóre cieszą się ogromnym prestiżem). Zob. A. Zagajewski, Poeci nie umarli, „Polityka”, 11-18 sierpnia 2007.

81 Tamże. 
konkursu zasiadają wybitni językoznawcy, profesorowie Jerzy Bralczyk, Andrzej Markowski i Michał Głowiński.

Najnowszą, niezwykle interesującą inicjatywą dotyczącą języka, a służącą upowszechnianiu szacunku dla regionalizmów i gwar oraz przeciwdziałaniu ich zanikowi (jak stanowi pkt. 4. Ustawy o ochronie języka polskiego) - jest decyzja dyrektora Muzeum Śląskiego Leszka Jodlińskiego dotycząca wprowadzenia mowy śląskiej na salony ${ }^{82}$, czyli do sal muzeum. Jak dowiadujemy się $z$ prasy ${ }^{83}$, wystawom poświęconym tematyce regionalnej mają towarzyszyć prelekcje po śląsku; uruchomione zostaną również kursy językowe.

Różnorodność przedstawionych tu propozycji nie powinna uśpić naszej czujności. Wręcz przeciwnie, konieczne są dalsze starania służące promocji języka ojczystego. Jako jedno z najważniejszych zadań postrzegam promowanie języka inkluzywnego, przyjaznego dla kobiet.

Konieczna jest aprobata dla szerokiego zainteresowania językiem ojczystym — jest on bowiem narzędziem naszej pracy naukowej i dydaktycznej, a zarazem — narzędziem oddziaływania wychowawczego.

\section{THE NATIVE LANGUAGE, A NEGLECTED AREA OF EDUCATION}

\section{Summary}

The author approaches native languages from the pedagogical point of view, perceiving language as an invisible environment of the upbringing of youths. She indicates the value of the national language in the past as well as currently in the period of globalization, she draws attention to the necessity to protect it and the importance of the Act on the Protection of the Polish Language introduced (1999) with this aim in mind. Analyzing current linguistic modes she gives many examples of carelessness and infringements of the principles of the use of the native language. She points out that respect for the language used is an element of good upbringing. An additional element of the discussion is the expression in the language of the oppression of women, so-called linguistic sexism. The article ends with a demonstration of examples of good practice - activities promoting linguistic culture, including language sensitive to gender issues (inclusive).

\section{Key words/słowa kluczowe}

national language / język ojczysty; influence of upbringing / wychowawcze oddziaływanie; value of language / wartość języka; linguistic sexism / seksizm językowy

82 Choć mowy śląskiej nie ma w urzędowym spisie języków regionalnych, to jest narzędziem codziennego komunikowania się tysięcy ludzi.

83 P. Jedlecki, Koniec gadania o godce. Czas się jej uczyć, „Gazeta Wyborcza”, 17 września 2009. 